\title{
Menakar Arah Demokrasi Konstalasi Partai Politik Dalam Proses Pemilihan Umum Pasca Reformasi
}

\author{
Fakhrurrozi Arrusadi \\ Magister Ilmu Hukum Universitas Islam Indonesia Yogyakarta Indonesia \\ Jln. Cik Di Tiro No. 1 Yogyakarta Indonesia \\ rozifraf@gmail.com
}

\begin{abstract}
Abstrak
The purpose of this study is to identify and further examine whether the role of political parties has reached the direction of democratic political consolidation after the 1998-2019 Reformation. The research method used is normative method by utilizing secondary data sources obtained through literature, books, legal materials, etc. The results of the study conclude that the role of political parties is still lacking in carrying out their functions as participatory political communities in democracy. The orientation of political parties is only used as a means to obtain the legality of power in the political struggle of general election democracy, including the role of political parties that tend to be oligarchic, political parties sometimes act loudly for and on behalf of the people's interests, but in fact they fight for the interests of their administrators. themselves, namely the elite and party rulers.
\end{abstract}

Key Words: Democracy; general election; political parties

\begin{abstract}
Abstrak
Tujuan penelitian ini untuk mengetahui dan mengkaji lebih jauh apakah peran partai politik telah mencapai arah konsolidasi politik demokratis pasca Reformasi Tahun 1998-2019. Metode Penelitian yang digunakan ialah metode normatif yang menggunakan sumber data sekunder atau data yang diperoleh melalui literatur kepustakaan, buku, bahan-bahan hukum, dll. Hasil penelitian menyimpulkan bahwa masih lemahnya peran partai politik dalam menjalankan fungsinya sebagai partisipatif masyarakat politik dalam berdemokrasi. Orentasi partai politik hanya dijadikan sebagai sarana untuk mendapatkan legalitas kekuasaan dalam pertarungan politik demokrasi pemilihan umum, diantaranya peran partai politik cendrung bersifat oligarkis, partai politik kadang-kadang bertindak dengan lantang untuk dan atas nama kepentingan rakyat, akan tetapi pada faktanya justru berjuang untuk kepentingan pengurusnya sendiri yakni para elit dan penguasa partai.
\end{abstract}

Kata-kata Kunci: Partai politik; demokrasi; pemilihan umum 


\section{Pendahuluan}

Reformasi 1998 adalah masa transisi kepemerintahaan dari bentuk kekuasaan otoritarianisme menuju demokrasi. Wajah baru kekuasaan demokrasi mengembalikan otoritas kekuasaan pada rakyat sebagai penentu segala kebijakan. Dampak dari peralihan ini ialah kekuasaan pemerintah tidak lagi berpusat pada satu lembaga pemerintahan yaitu eksekutif. Berbagai rekonsiliasi konstitusional di lakukan hingga terjadinya pengimbangan kekuasaan di tiap-tiap lembaga pemerintahan. Penyelenggaraan pemerintahan harus berdasarkan fungsi kelembagaan dalam proses penyelenggaraan pemerintahan yang demokratis konstitusional.

Negara Indonesia adalah negara yang berdasarkan hukum sebagaimana bunyi Pasal 1 ayat (3) UUD 1945. Dalam membangun sebuah negara hukum yang demokratis, tidak terlepas dari peran setiap lembaga negara dalam pelaksanaan fungsi kepemerintahan. Berbagai masalah yang berkaitan dengan hak konstitusional warga negara harus dilindungi oleh negara. Dalam pelaksanaannya lembagalembaga negara yang diamanatkan oleh konstitusi bertugas memberikan perlindungan terhadap hak konstitusional warga negara, menjunjung tinggi nilai keadilan, kepastian, dan kemanfaatan hukum yang berperikemanusiaan.

Dalam penyelenggaraan negara demokrasi konstitusional tidak terlepas dari penganutan sistem demokrasi. Demokrasi dipilih karena dinilai paling baik dibanding sistem yang lain. Kesadaran akan hak dan kewajiban merupakan wujud perlindungan negara terhadap hak konstitusional dan hak asasi manusia. Perlindungan tersebut adalah nilai esensial dalam kehidupan berdemokrasi. Demokrasi merupakan sistem penyelenggaraan pemerintahan. Dalam wujud negara modern, demokrasi di maknai sebagai bentuk kekuasaan yang dimiliki oleh kaum mayoritas "Rakyat" dalam suatu negara. Sebagai kekuasaan dari rakyat oleh rakyat dan untuk rakyat, demokrasi sudah seharusnya dijalankan sepenuhnya oleh "Pemangku Kebijakan" sebagai kekuasaan untuk memerintah dan atau menjalankan pemerintahan menurut undang-undang. ${ }^{1}$

Pelaksanaan demokrasi dengan sistem pemilihan umum sejak 2002 telah dikembalikan kepada rakyat untuk memilih siapa yang akan menjadi pemimpin bangsa sesuai kehendak rakyat. Pemilihan umum tersebut dilakukan secara demokratis berdasarkan asas jujur, adil, bebas, dan rahasia. Akan tetapi di 2002 adalah masa percobaan dikarenakan kondisi perpolitikan bangsa pada waktu itu terjadi pro dan kontrak dalam pencalonan kandidat partai. Wujud pembaharuan

1 Myaskur, "Implementation of Sustainable Prophetic Electoral Rights in the General Election Process”, 2 (1) Prophetic Law Review 97, 2020, hlm. 98-100 
sistem demokrasi ditandai dengan dikeluarkannya Undang-Undang Nomor 12 Tahun 2003 tentang Pemilihan Umum. Berdasarkan peraturan tersebut, pada 2004 menjadi momentum pemilihan umum Presiden, DPR, DPRD, dan DPD yang dilaksanakan di tiap ibukota provinsi dan kabupaten kota di seluruh indonesia.

Pada saat sekarang, aturan tentang pemilihan umum merujuk pada UndangUndang Nomor 7 Tahun 2017 tentang Pemilihan Umum. Ada banyak perbedaan UU Nomor 7 Tahun 2017 tentang Pemilihan Umum dengan Undang-Undang terkait yang berlaku sebelumnya. Seperti UU Nomor 42 Tahun 2008 tentang Pemilihan Umum Presiden dan Wakil Presiden, UU Nomor 15 Tahun 2011 tentang Penyelenggaraan Pemilihan Umum dan UU Nomor 8 Tahun 2012 tentang Pemilihan Umum Anggota DPR, DPD, dan DPRD. Perbedaan mendasar adalah bahwa pelaksanaan Pemilu Presiden dan Wapres serta Pemilu Anggota DPR, DPD dan DPRD yang dulunya terpisah sekarang dilaksanakan secara bersamaan. ${ }^{2}$

Bentuk demokrasi dengan sistem perwakilan yang dilaksanakan lima tahun hanya sebagai tuntutan pelaksanaan demokrasi yang sifatnya prosedural. Dalam wujud peroses pelaksanaan demokrasi prosedural telah meniadakan esensi kedaulatan rakyat sebagai pemberi kekuasaan demokrasi yang sesungguhnya. Hal tersebut dikarenakan dalam pelaksanaan pemilihan umum potensi kecurangan akan terjadi. Berbagai upaya akan dilakukan oleh tiap-tiap elit politisi parpol untuk mendapatkan kemenangan sebagai peserta politik dalam pemilu sehingga penentuan suara bukan berdasarkan kesadaran kehendak masyarakat. Demokrasi pemilihan umum tiada lain adalah mobilisasi suara kemenangan melalui intervensi kekuasaan politik dalam insitusi/lembaga penyelenggaran pemilu yang memonopoli kekuasaannya secara struktural, sistematis, dan masif.

Praktek penyelenggaran demokrasi dipahami dan dijalankan secara berbeda-beda, sehingga timbul masalah antara wakil dan yang diwakilinya. Apa yang dilakukan oleh wakil-wakil rakyat dalam lembaga perwakilan tidak selamanya dapat diterima oleh rakyat. Keadaan ini sering muncul menjadi permasalahan dalam praktek demokrasi, berkaitan dengan pilihan akan dilaksanakannya demokrasi elitis atau demokrasi partisipatoris. Demokrasi elitis adalah demokrasi yang semu, hanya diperankan oleh sekelompok orang yang mengatasnamakan rakyat melalui justifikasi pemilihan umum.

Demokrasi yang diselenggarakan lima tahun sekali melalui sistem pemilihan umum bukan lagi sebagai partisipasi kehendak rakyat dalam pemilu. Sesungguhnya demokrasi dalam pemilihan umum adalah ajang pertarungan politik oleh para elit partai dalam memperebutkan kekuasaan rakyat. Untuk hal

2 Al Mas'udah, "The Presidential Treshold as an Open Legal Policy in General Elections in Indonesia”, 2 (1) Prohpetic Law Review 37, 2020, hlm. 38-41. 
tersebut, berbagai instrument kejahatan dilakukan untuk memperoleh legalitas suara kemenangan dari lembaga yang dipercayai dalam penyelenggaraan pemilu.

Pelaksanaan demokrasi dalam sistem multi partai merupakan bentuk kelemahan demokrasi yang diterapkan di Indonesia. Dalam struktur bangunan sosial kehidupan masyarakat, Indonesia memiliki perbendaan ras dan pahaman secara plural. Selain itu, secara geografis Indonesia berbentuk kepulauan hingga memungkinkan pelaksanaan demokrasi tidak sepenuhnya berjalan sesuai dengan kehendak rakyat dan konsitusi negara. Dalam pelaksanaan sistem demokrasi di era digital, kehadiran media memiliki peran yang amat penting dalam proses penyelenggaraan demokrasi tetapi peran media sekarang lebih kepada simbol untuk meningkatkan popularitas melalui politik pencitraan yang di praktekkan para politisi.

Salah satu bentuk kegagalan demokrasi adalah lemahnya tingkat kesadaran masyarakat terhadap wujud esensial demokrasi yang sesungguhnya. Proses penyelenggaraan pemilihan umum sebagai bentuk penggunaan hak politik cenderung bersifat mobilisasi yang meniadakan kesadaran terhadap partisipasi politik. Di dalam demokrasi, pertentangan politik memperoleh sifat siklikal. Pemilihan umum, dalam jangka waktu teratur dan pasti, mempunyai efek mengubah negara secara keseluruhan menjadi medan pertempuran politik, di mana nasib tergantung dari hasil pemilihan tersebut. Semua tindakan koersif kekuasaan, seluruh aparat untuk memaksakan kepatuhan, dengan demikian dilepaskan oleh orang yang kalah dan di berikan ke tangan pemenang. Pemilihan umum dengan demikian secara sangat alamiah menjadi momen yang menentukan bagi pertempuran itu. Perjuangan-perjuangan politik terjadi menurut pola yang ritmisi, melalui fase aktivitas yang seru setiap empat atau lima tahun dalam skema dan penyusunan strategi yang kontinyu. Dengan berbagai fraksi masuk dan gugur, akan tetapi setiap gelombang politik rakyat hanya terjadi di bawah kesempatan-kesempatan yang secara kebetulan sama. Diluar pemilihan umum, perjuangan politik di dalam negara-negara demokrasi melanjutkan sifat terbuka dan kontinyu yang sama. Di dalam polemik-polemik surat kabar, di dalam pertemuan dan diskusi, berbagai organisasi pergumulan tetap berlanjut dengan disaksikan secara penuh oleh setiap orang, karena di dalam demokrasi, sejumlah politik tertentu berlangsung di balik pintu tertutup. Fakta tentang pembiayaan kampanye atas campur tangan dari kepentingan pribadi tertentu di dalam pemerintahan dan administrasi, dalam prakteknya, suara bulat dan 
kesatuan lebih merupakan sesuatu yang "kelihatannya" dari pada sebenarnya. Perjuangan politik terjadi, akan tetapi bersembunyi atau berkamuflase. ${ }^{3}$

Hasil pemilihan umum merupakan suatu dari hasil kompetisi politik antar peserta pemilihan umum, karena kualitas demokrasi sangat tergantung kepada kualitas hasil pemilihan umum. Oleh sebab itu, Pasal 22E ayat (1) UUD 1945 menentukan, "Pemilihan umum dilaksanakan secara langsung, umum, bebas, rahasia, jujur, dan adil setiap lima tahun sekali". Pada pokoknya, perkara perselisihan hasil pemilu itu merupakan perkara perselisihan antardua pihak, yaitu pihak peserta pemilu versus pihak penyelenggaraan pemilu, yaitu Komisi Pemilihan Umum. Peserta pemilu untuk pemilu calon anggota DPR (Dewan Perwakilan Rakyat) dan DPRD (Dewan Perwakilan Rakyat Daerah) adalah partai politik yang bersangkutan, sedangkan peserta pemilu untuk pemilu calon anggota DPD (Dewan Perwakilan Daerah) adalah perseorangan yang telah memenuhi kualifikasi persyaratan. Sementara itu, peserta pemilu untuk pemilu Presiden adalah pasangan calon Presiden dan calon Wakil Presiden yang bersangkutan. Komisi Pemilihan Umum sebagai institusi penyelenggaraan pemilu. Artinya, KPUD di daerah dianggap hanya sebagai bagian dari KPU tingkat pusat. Demikian pula partai politik sebagai peserta pemilu dipandang sebagai satu kesatuan insitusi badan hukum. Oleh karena itu, Pengurus Wilayah Partai Polituk bersangkutan tidak dapat tampil tersendiri diluar kesatuan unit kelembagaan dengan kepengurusan di tingkat pusat. ${ }^{4}$

\section{Rumusan Masalah}

Berdasarkan latar belakang di atas, rumusan masalah dalam penelitian ini adalah: Apakah peran partai politik dalam proses demokrasi pemilihan umum pasca reformasi 1998-2019 sudah mencapai arah konsolidasi politik yang demokratis?

\section{Tujuan Penelitian}

Tujuan dalam penelitian ini adalah: Untuk Mengetahui dan mengkaji peran partai politik dalam mencapai arah konsolidasi politik demokratis pasca reformasi 1998-2019.

${ }^{3}$ Maurice Duvergere, The Study Of Politics. Terjemah, Daniel Dhakidae, Sosiologi Politik, Cetakan Keempat, Raja Grafindo Persada, Jakarta, 1993, hlm. 136.

4 Jimly Asshiddiqie, Pengantar Ilmu Hukum Tata Negara, Cetakan Kesembilan, Rajawali Pers, Depok, 2017, hlm. 274. 
Metode Penelitian

Metode yang digunakan dalam penelitian ini adalah metode penelitian yang bersifat penelitian normatif yang menggunakan sumber data sekunder atau data yang diperoleh melalui literatur kepustakaan, buku, bahan-bahan hukum, dll.

\section{Hasil Penelitian dan Pembahasan}

\section{Arah Demokrasi Konstalasi Partai Politik dalam Pemilihan Umum Pasca Reformasi}

Era reformasi telah membawa perubahan yang signifikan bagi Indonesia. Di antara perubahan-perubahan tersebut adalah amandemen Undang-Undang No. 3 Tahun 1999 tentang Pemilihan Umum menjadi Undang-Undang No. 12 Tahun 2003. Sebagaimana diketahui, sistem pemilihan yang diterapkan adalah sistem proposional yakni terbuka untuk memilih anggota DPR dan DPRD. Menjelang pemilu 2004, faktor-faktor yang mendorong pendirian parpol bertambah. Pertama, Pemilu 2004 lebih bernilai strategis, mengingat sudah disepakati di Pasal 6A Amandemen ke-3 UUD 1945 bahwa pemilihan presiden dan wakil presiden dilakukan satu paket yang secara langsung dipilih oleh rakyat dan diajukan oleh partai politik atau gabungan partai politik. Secara teoritik partai politik yang memenuhi syarat sebagai partai politik peserta pemilu dapat mengikuti ajang dalam pencalonan presiden dan wakil presiden. Kedua, perpecahan yang terjadi di sejumlah partai politik dapat berakibat adanya kepengurusan partai politik baru. Ketiga, pendirian parpol baru dinilai dapat memperhitungkan posisi tawar politik dan memperlebar akses masuk ke lingkungan penyelenggaraan kekuasaan negara.

Persyaratan bagi partai politik peserta pemilihan umum 2004, khususnya syarat minimal peserta perolehan kursi di lembaga perwakilan rakyat, telah menjadi bahan perdebatan sengit dalam pembahasan RUU Pemilu, karena hanya empat partai politik yang terwakili di DPR yang memenuhi syarat yakni, PDIP, Partai Golkar, PPP, PKB, PAN, dan PBB. ${ }^{5}$ Dalam pelaksanaan demokrasi hal demikian tidak terlepas dari penganutan sistem kepartaian yaitu sistem multi partai. Di karenakan keberataan partai politik sebagai peserta dalam pemilihan umum, sehingga pada 2002 diterbitkan Undang-Undang No. 31 tentang Partai Politik. Peran partai politik sebagaimana yang dijelaskan dalam UU No. 2 Tahun 2011, tentang perubahan atas UU No. 2 Tahun 2008 tentang partai politik adalah bentuk persyaratan terhadap pelaksanaan demokrasi dalam sistem pemilihan umum. hlm. 74 .

${ }^{5}$ Koirudin, Partai Politik dan Agenda Tansisi Demokrasi, Cetakan Kedua, Pustaka Pelajar, Yogyakarta, 2015, 
Mengutip pendapat Miriam Budiardjo, ada empat fungsi yang dimiliki oleh partai politik meliputi sarana: komunikasi politik, sosialisasi politik, rekruitmen politik, dan pengaturan konflik. Dalam istilah Yves Menydan And Knapp, fungsi partai politik itu mencakupi fungsi, mobilisasi dan integrasi, saran pembentukan pengaruh terhadap perilaku memilih, sarana rekrutme npolitik, dan sarana elaborasi pilihan-pilihan kebijakan. Dari keempat fungsi tersebut sama-sama berkaitan satu dengan yang lainnya. Sebagai sarana komunikasi politik, partai berperan sangat penting dalam upaya mengartikulasikan kepentingan atau yang terdapat atau kadang-kadang yang tersembunyi dalam masyarakat. Berbagai kepentingan itu diserap sebaikbaiknya oleh partai politik menjadi ide-ide, visi, dan kebijakan-kebijakan partai politik yang bersangkutan. Setelah itu, ide-ide dan kebijakan atau aspirasi kebijakan itu diadvokasikan sehingga dapat diharapkan memengaruhi atau bahkan menjadi materi kebijakan kenegaraan yang resmi. ${ }^{6}$

Dalam penerapan sistem kepartaian dengan corak penganutan sistem dua partai atau multi partai, sebagian besar merupakan akibat dari faktor-faktor sosio ekonomi. Partai-partai mencerminkan kelas-kelas sosial dan kelompok-kelompok sosial yang berbeda dalam konflik satu sama lain. Konflik antar kelompokkelompok sosial berkembang dalam konteks kultur sistem pemilihan yang cenderung mempertahankan dan memperkuat faktor-faktor sosio ekonomi dan kultur yang inheren. Di dalam demokrasi pemilihan umum yang diselenggarakan melalui proses pemilihan umum secara langsung oleh rakyat, kompetisi politiknya lebih ril, lebih mendasar, lebih dirasa secara sadar oleh masyarakat dalam menggunakan hak pilihnya. Hubungan antara sistem pemilihan dan sistem kepartaian menunjuk jelas otonomi lembaga-lembaga. Pengaturan yang khusus dari satu lembaga (sistem pemilihan) memberikan kepada lembaga-lembaga lain (sistem partai) konfigurasi tertentu yang pada gilirannya mempengaruhi antagonisme politik dengan mengidentifikasikan atau menahannya. ${ }^{7}$

Adanya organisasi politik "partai politik" dapat juga mengandung beberapa kelemahan. Dalam praktek pelaksanaan sistem kepartaian yang tidak sesuai dengan peran dan fungsinya dikarenakan orientasi partai politik hanya dijadikan sebagai sarana untuk mendapatkan legalitas kekuasaan dalam pertarungan politik demokrasi pemilihan umum. Peran partai politik cenderung bersifat oligarkis, partai politik kadang-kadang bertindak dengan lantang untuk dan atas nama kepentingan rakyat, akan tetapi pada faktanya justru berjuang untuk kepentingan pengurusnya sendiri yakni para elit dan penguasa partai.

\footnotetext{
${ }^{6}$ Jimly Asshiddiqiue, Pengantar Ilmu..., Op. Cit., hlm. 406-407.

${ }^{7}$ Maurice Duvergere, The Study..., Op. Cit, hlm. 120.
} 
Seperti yang dikemukakan oleh Robert Michels, sebagai suatu hukum besi yang berlaku dalam organisasi, "Organisasilah yang melahirkan dominasi si terpilih atas peran pemilihnya, antara si mandataris dengan si pemberi mandate dan antara si penerima kekuasaan dengan sang pemberi. Siapa saja yang berbicara tentang organisasi, maka sebenarnya ia berbicara tentang oligarki". Pelaksanaan sistem demokrasi pemilihan umum berjalan sejak di awal 2004 hingga di 2019 dilaksanakan demokrasi pemilihan umum secara serentak di tiap provinsi dan kabupaten kota di seluru indonesia guna untuk memili Presiden dan Wakil Presiden, DPR, DPRD, namun hal itu terkesan miris, dikarenakan berbagai kejahatan bisa dipergunakan untuk merebut kekuasaan pemerintahan di karenakan pesta demokrasi pemilihan umum hanya dijadikan sebagai ajak pertarungan kekuasaan ditiap kontestasi politik pelaksanaan pemilihan umum.

Undang-Undang Republik Indonesia Nomor 7 Tahun 2017 tentang Pemilihan Umum menegaskan, Pemilu dilaksanakan berdasarkan asas langsung, umum, bebas, rahasia, jujur, dan adil. Dalam penyelenggaraan pemilu, penyelenggara pemilu harus berdasarkan pada asas-asas tersebut. Pemilu sebagai sarana perwujudan kedaulatan rakyat guna menghasilkan pemerintahan negara yang demokratis berdasarkan Pancasila dan UUD 1945 dimaksudkan untuk memilih presiden dan wakil presiden, anggota DPR, DPD, DPRD, serta kepala daerah dan wakil kepala daerah yang mampu mencerminkan nilai-nilai demokrasi dan dapat menyerap serta memperjuangkan aspirasi rakyat sesuai dengan tuntutan perkembangan kehidupan berbangsa dan bernegara.

Dalam sistem representatif, demokrasi bisa dimengerti sebagai bentuk partisipasi rakyat yang disalurkan melalui pengumutan suara rakyat untuk membentuk lembaga perwakilan. Mekanisme perwakilan ini dianggap dengan sendirinya efektif untuk maksud menjamin keterwakilan aspirasi atau kepentingan rakyat. Oleh karena itu, dalam sistem perwakilan, kedudukan dan peran partai politik dianggap sangat dominan.

Terselenggaranya pemilu secara demokratis menjadi dambaan setiap warga Negara Indonesia. Pelaksanaan pemilu dikatakan berjalan secara demokratis apabila setiap warga negara Indonesia yang mempunyai hak pilih dapat menyalurkan pilihannya secara langsung, umum, bebas, rahasia, jujur, dan adil. Setiap pemilih hanya menggunakan hak pilihnya satu kali dan mempunyai nilai yang sama, yaitu satu suara. Hal ini yang sering disebut dengan prinsip one person, one vote, one value (opovov). Dan pemilu yang bersifat langsung adalah rakyat sebagai pemilih berhak untuk memberikan suaranya secara langsung sesuai dengan kehendak hati nuraninya tanpa perantara. 
Warga negara yang memenuhi persyaratan sebagai pemilih berhak mengikuti pemilu dan memberikan suaranya secara langsung. Sedangkan pemilu yang bersifat umum mengandung makna terjaminnya kesempatan yang sama bagi semua warga negara, tanpa diskriminasi. Pemilu yang bersifat bebas berarti bahwa setiap warga negara yang berhak memilih bebas untuk menentukan pilihannya tanpa tekanan dan paksaan dari siapa pun. Dalam melaksanakan haknya, setiap warga negara dijamin keamanannya, sehingga dapat memilih sesuai dengan kehendak hati nurani dan kepentingannya. Pemilu yang bersifat rahasia berarti bahwa dalam memberikan suaranya, pemilih dijamin pilihannya tidak akan diketahui oleh pihak manapun dan dengan jalan apa pun.

Selanjutnya, pemilihan umum diselenggarakan oleh penyelenggara pemilu yang mempunyai integritas, profesionalitas, dan akuntabilitas yang dilaksanakan secara lebih berkualitas, sistematis, legitimate, dan akuntabel dengan partisipasi masyarakat seluasluasnya. Dalam penyelenggara pemilu, aparat pemerintah, peserta pemilu, pengawas pemilu, pemantau pemilu, pemilih, dan semua pihak yang terkait harus bersikap dan bertindak jujur sesuai dengan peraturan perundang-undangan. Pemilih dan peserta pemilu mendapat perlakuan yang sama dan bebas dari kecurangan atau perlakuan yang tidak adil dari pihak mana pun. Pemilu harus dilaksanakan secara lebih berkualitas agar lebih menjamin kompetisi yang sehat, partisipatif, mempunyai derajat keterwakilan yang lebih tinggi, dan memiliki mekanisme pertanggungjawaban yang jelas, apakah itu dalam bentuk pemilihan presiden maupun kepala daerah, harus berdasarkan kesadaran pastisipasi masyarakat dalam menggunakan hak politiknya untuk memilih. Disinilah arti pentingnya tokoh masyarakat, pers dan partai politik, ikut ambil bagian dalam proses penyelenggaraan pemerintahan. Kekuatan-kekuatan politik ini merupakan kekuatan infra struktur politik yang perlu diberikan tempat secara proposional dalam demokrasi partisipatoris. Demokrasi yang secara sadar akan memberdayakan rakyat dalam rangka mewujudkan pemerintahan 'dari rakyat, oleh rakyat dan untuk rakyat dan bersama rakyat'. Adanya pemberdayaan rakyat yang akan berupa partisipasi langsung ini penting, karena sistem perwakilan rakyat melalui lembaga perwakilan tidak pernah dapat diandalkan sebagai satusatunya saluran aspirasi rakyat. Karena itulah, prinsip 'representation in ideas' dibedakan dari 'representation in presence', karena perwakilan fisik saja belum tentu mencerminkan keterwakilan gagasan atau aspirasi. Dalam demokrasi elitis, peran rakyat digantikan oleh sekelompok elit politik dalam melaksanakan pemerintahan. Setelah dilakukannya pemilihan umum, maka proses bernegara dalam pengambilan keputusan-keputusan publik, sepenuhnya diwakili oleh lembaga perwakilan. Lembaga perwakilan akan menjalankan tugas dan fungsinya secara 
bebas tanpa dibayangi oleh kontrol dan protes dari rakyatnya. Di bawah sebuah pemerintahan perwakilan ini, warga negara sering menyerahkan kekuasaan yang sangat besar yang dapat digunakan sesukanya atas keputusan-keputusan yang luar biasa penting. Inilah sisi gelap dari demokrasi perwakilan, walaupun diakui juga ada keuntungan-keuntungannya.

Dalam penerapan sistem kepartaian dengan corak penganutan sistem dua partaia tau multi partai, sebagian besar merupakan akibat dari fakto-faktor sosio ekonomi, partai-partai mencerminkan kela-kelas sosial dan kelompok-kelompok sosial yang berbeda dalam konflik satu sama lain, konflik antara kelompokkelompok sosial berkembang dalam kontekskultur sistem pemilihan yang cendrung mempertahankan dan memperkuat fakto-faktor sosio ekonomi dan kultur yang inheren. Di dalam demokrasi pemilihan umum yang diselenggarakan melalui proses pemilihan umum secara langsung oleh rakyat kompetisi politiknya lebihril, lebih mendasar, lebih dirasa secara sadar oleh masyarakat dalam menggunakan hak pilihnya dalam pemilihan umum. Hubungan antara sistem pemilihan dan sistem kepartaian menunjukan secara amat jelas otonomi lembaga-lembaga. Pengaturan yang khusus dari satu lembag (sistem pemilihan) memberikan kepada lembaga-lembaga lain (sistem partai) konfigurasi tertentu yang pada gilirannya mempengaruhi antagonisme politik dengan mengidentifikasikan atau menahannya. ${ }^{8}$

\section{Penutup}

Adanya organisasi politik "partai politik" tentu dapat juga mengandung beberapa kelemahan dalam wujut peraktek pelaksanaan sistem kepartaian yang tidak sesuai dengan peran dan fungsinya sebagai peserta pemilihan umum dalam pemilihan umum yang demokratis, dikarenakan orentasi partai politik hanya dijadikan sebagai sarana untuk mendapatkan legalitas kekuasaan dalam pertarungan politik demokrasi pemilihan umum, diantaranya peran pertai politik cendrung bersifat oligarkis, partai politik kadang-kadang bertindak dengan lantang untuk dan atas nama kepentingan rakyat, akan tetapi pada faktanya justru berjuang untuk kepentingan pengurusnya sendiri yakni para elit dan penguasa partai. Seperti yang dikemukakan oleh Robert Michels, sebagai suatu hukum besi yang berlaku dalam organisasi, "Organisasilah yang melahirkan dominasi sitem pilihan atas peran pemilihnya, antara si mandataris dengan si pemberi mandate dan antara si penerima kekuasaan dengan sang pemberi. Siapas aja yang berbicara tentang organisasi, maka sebenarnya ia berbicara tentang oligarki".

${ }^{8}$ Maurice Duvergere, The Study..., Ibid., hlm. 120. 
Peran partai politik dalam proses demokrasi pemilihan umum sebagaimana yang dijelaskan oleh Solly Lubis adalah orentasi Parpol dan Caleg di saat-saat Pemilu, bukan soal mempersiapkan bekal sebagai wakil rakyat, tetapi adalah pergulatan dalam hal percalegan bersaing untuk menjadi utusan parpol dengan berbagai dukungan dan resiko. Tegasnya perlu disadari bahwa parpol yang nengutus para calon harus mempunyai tanggung jawab yang berat secara organisatoris, mengenai kualitas oknum-oknum yang diusutnya dalam pencalonan sebagai perwakilan rakyat yang mencakupi latar blakang pendidikan dan pengalaman anggotanya sebelum manggung di badan perwakilan rakyat. ${ }^{9}$

Salah satu bentuk kegagalan demokrasi adalah lemahnya peran partai politik dalam menjalankan fungsinya sebgai partisipatif masyarakat politik dalam berdemokrasi, hingga proses penyelenggaraan demokrasi pemilihan umum memicu pertarungan politik. Konflik politik di dalam demokrasi bersifat resmi yaitu dikenal dan diakui. Sangat sengit selama kampanye pemilihan umum, akan tetapi berlanjut dalam masa antar pemilihan umum. Di dalam demokrasi pertentangan politik memperoleh sifat siklikal. Pemilihan umum, dalam jangka waktu teratur dan pasti, mempunyai efek mengubah Negara secara keseluruhan menjadi medan pertempuran politik, di mana tergantung dari hasil pemilihan tersebut. Semua tindakan koersif kekuasaan, seluruh aparat untuk memaksakan kepatuhan, dengan demikian dilepaskan oleh orang yang kalah dan di berikan ketangan pemenang. Pemilihan umum dengan demikian secara sangat alamiah menjadi momen yang menentukan bagi pertempuran itu, perjuangan-perjuangan politik terjadi menurut pola yang ritmisi, melalui fase aktivitas yang seru setiap empat atau lima tahun dalam skema dan penyusunan strategi yang kontinyu, dengan berbagai frasksi masuk dan gugur, akan tetapi setiap gelombang kegairaan politik rakyat hanya terjadi di bawah kesempatan-kesempatan yang secara kebetulan sama.

Di luar pemilihan umum, perjuangan politik di dalam negara-negara demokrasi melanjutkan sifat terbuka dan kontinyu yang sama, di dalam polemikpolemik surat kabar, didalam pertemuan dan diskusi, berbagai organisasi pergumulan tetap berlanjut dengan disaksikan secara penuh oleh setiap orang, karena di dalam demokrasi, sejumlah politik tertentu berlangsung di balik pintu tertutup, fakta tentang pembiayaan kampanye atas campur tangan dari kepentingan pribadi tertentu didalam pemerintahan dan administrasi, dalam prakteknya, suara bulat dan kesatuan lebih merupakan sesuatu yang

9 Solly Lubis, Politik. Hukum dan Kebijakan Publik, Cetakan Pertama, CV. Mandar Maju, Bandung, 2014, hlm. 104. 
"kelihatannya" daripada sebenarnya. Perjuangan politik terjadi, akan tetapi bersembunyi atau berkamuflase. ${ }^{10}$

Dari beberapa uraian mengenai fungsi partai politik di atas, kita melihat bahwa ada fungsi yang sudah berjalan dengan baik, tapi masih banyak fungsi lain yang belum berjalan. Dengan demikian agenda yang kita desakkan ke parpolparpol di Indonesia adalah menjalankan semua fungsinya secara seimbang. Fungsi-fungsi tersebut harus dilihat sebagai organ yang saling berkaitan. Selama ini parpol hanya berfungsi untuk berebut kekuasaan dan mengesampingkan fungsi lainnya. Memang harus diakui bahwa hingga saat ini partai politik kita masih jauh dari kondisi memadai sebagai penyaluran aspirasi antara janji politik partai dengan realitas produk kebijakan publik, memang masih banyak pekerjaan rumah yang harus diselesaikan. ${ }^{11}$

Di samping persoalan-persoalan tersebut, perspektif perubahan sistem pemilu harus dikaji dalam konteks konsolidasi demokrasi konstitusional, terutama dalam kaitannya dengan pengembangan fungsi-fungsi demokratis politik "masyarakat sipil" dengan membuka seluas-luasnya saluran-saluran bagi agregasi dan artikulasi serta representasi kepentingan baik melalui orsospol. Ormas maupun melalui kelompok-kelompok kepentingan (interest group) dan kelompok-kelompok penekan (pressure group) lainnya yang ada di masyarakat.

\section{Daftar Pustaka}

\section{Buku}

Asshiddiqie, Jimly, Pengantar Ilmu Hukum Tata Negara, Cetakan Kesembilan, Rajawali Pers, Depok, 2017.

Duvergere, Maurice, The Study Of Politics, Terjemah, Daniel Dhakidae, Sosiologi Politik, Cetakan Keempat, Raja Grafindo Persada, Jakarta, 1993.

Koirudin, Partai Politik dan Agenda Tansisi Demokrasi, Cetakan Kedua, Pustaka Plajar, Yogyakarta, 2015.

Lubis, Solly, Politik Hukum dan Kebijakan Publik, Cetakan Pertama, CV. Mandar Maju, Bandung, 2014.

\section{Jurnal}

Al Mas'udah, "The Presidential Treshold as an Open Legal Policy in General Elections in Indonesia", 2 (1) Prohpetic Law Review 37, 202

Myaskur, "Implementation of Sustainable Prophetic Electoral Rights in the General Election Process", 2 (1) Prophetic Law Review 97, 2020. 